\title{
THE EFFECTIVENESS OF DIRECT INTERACTION MODEL-ASSISTED MACROMEDIA FLASH ON COLLIGATIVE PROPERTIES OF SOLUTIONS MATERIAL
}

\author{
Fatayah $^{* 1}$, Kriesna Kharisma Purwanto ${ }^{2}$ \\ ${ }^{1}$ Program Studi Pendidikan kimia, FKIP, Universitas Billfath \\ ${ }^{2,}$ Program Studi Pendidikan Kimia, FKIP, Universitas Billfath \\ *Komplek Pondok Pesantren Al-Fattah Siman Sekaran Lamongan Jawa Timur 61156: \\ fatayahchemistry2308@gmail.com
}

\begin{abstract}
The purpose of this study was to determine the effectiveness of the use of direct instruction model-assisted macromedia flash. The effectiveness of the learning model are measured by two indicators, that are the activities of students during learning and the level of completeness of student learning outcomes after learning activities.The stages of this study consisted of two stages, namely pre-research and overcoming the learning difficulties of the colligative properties of the solutions by applying adirect instruction model-assisted macromedia flash. From the data analysis, it was known that (1) the activities of students during learning are at 4 and 5scores, (2)the average cognitive score of students was 78. From the results of this study, it can be concluded that the application of direct instruction modelassisted macromedia flash was effective to reduce learning difficulties of students on the colligative properties of the solutions material.
\end{abstract}

Keywords: effectiveness, direct instruction model, macromedia flash, colligative properties of solutions

\section{PENDAHULUAN}

Sifat koligatif larutan adalah salah satu materi kimia kelas XII. Sifat koligatif larutan merupakan materi yang dirasa sulit bagi kebanyakan siswa. Kemungkinan yang menjadi penyebab kesulitan tersebut diantaranya siswa belum memahami dengan baik konsep-konsep dasar yang menjadi prasyarat untuk mempelajari sifat koligatif, cara belajar siswa yang cenderung menghafal, dan hanya terpaku pada rumus-rumus untuk menyelesaikan soal algoritma/perhitungan.

Kesulitan belajar pada materi sifat koligatif larutan juga terjadi di MA di tiga Kecamatan yang ada di Kabupaten Gresik (Panceng, Ujung Pangkah dan Dukun). Hasil wawancara dengan beberapa guru kimia dan siswa, didapat temuan bahwa siswa kesulitan dalam memahami materi tersebut karena banyak konsep yang bersifat abstrak dan perhitungan matematis. Hasil penelitian diketahui hanya $50 \%$ siswa yang tuntas dalam pembelajaran sifat koligatif larutan (1). Hasil penelitian pendukung lainnya juga menunjukkan bahwa hanya $30 \%$ siswa yang mendapatkan predikat tuntas dalam pembelajaran sifat koligatif larutan (2). Alasan utama yang menjadi penyebab adalah banyaknya materi yang harus dipahami, namun guru menggunakan strategi pembelajaran yang kurang efektif untuk meningkatkan pemahaman siswa.

Hasil pra penelitian analisis materi sifat koligatif larutan dengan beberapa guru kimia juga diperoleh bahwa materi sifat koligatif larutan ini sarat akan simbol matematis, perlu penyelesaian beberapa tahapan sehingga perlu penjelasan tahap demi tahap dan juga perlu memodelkan dengan beberapa contoh soal. Model pembelajaran merupakan model yang dipilih dalam rencana pembelajaran dengan menggunakan suatu sintaks (langkah-langkah 
yang sistematis dan urut) guna mencapai tujuan pembelajaran(3). Model pengajaran langsung dirancang khusus untuk menunjang proses belajar siswa yang berkaitan dengan pengetahuan deklaratif dan prosedural yang terstruktur dengan baik, yang dapat diajarkan dengan pola kegiatan yang bertahap, selangkah demi selangkah. Model tersebut bertumpuh pada prinsip-prinsip psikologi perilaku dan teori belajar sosial(4). Sintaks model pembelajaran langsung adalah sebagai berikut: (1) menyampaikan tujuan dan mempersiapkan siswa, (2) mempresentasikan atau mendemonstrasikan pengetahuan dan keterampilan, (3) membimbing pelatihan, (4) mengecek pemahaman siswa dan memberikan umpan balik, (5) memberikan kesempatan untuk pelatihan lanjutan dan penerapan (4).

Selain menggunakan model pembelajaran yang sesuai, solusi alternatif untuk mengatasi kesulitan belajar adalah dengan penggunaan media pembelajaran interaktif. Media pembelajaran yang sering digunakan dalam menunjang pembelajaran kimia adalah media berbasis komputer. Macromedia flash adalah media berbasis komputer dan media tersebut yang sering digunakan. Pembelajaran akan menjadi lebih dinamis dan efektif jika menggunakan media pembelajaran berbantuan macromedia flash karena dapat menyatukan teks, grafik, animasi, audio, dan video. Media ini mampu menyajikan konsep-konsep kimia secara lebih menarik melalui tampilan gambar, animasi, video, dan suara serta diharapkan mampu membantu mengurangi kesulitan belajar yang dialami siswa. Hasil penelitian tentang penggunaan aplikasi laboratorium virtual berbasis macromedia flash dapat menjadikan prestasi dan motivasi belajar siswa meningkat karena memberikan suasana lingkungan belajar yang menarik (5). Berikutnya, hasil penelitian yang serupa juga menunjukkan bahwa penggunaan "papan tulis interaktif" berbasis macromedia flash mampu memotivasi siswa untuk aktif dalam pembelajaran, menciptakan suasana belajar yang menarik, antusias, dan menyenangkan (6). Penelitian sejenis juga memperlihatkan bahwa penggunaan laboratorium virtual berbasis macromedia flash memiliki manfaat, yaitu (1) siswa fokus pada proses menggantiganti bahan dan peralatan selayaknya melakukan kegiatan praktikum di laboratorium sebenarnya,(2) pemahaman konsep siswa pada level makroskopis, mikroskopis dan simbolis dapat diteliti lebih detail dengan media virtual, dan (3) software memberikan siswa kesempatan untuk menerapkan pengetahuannya dalam kehidupan sehari-hari (7).

Penelitian lain menunjukkan bahwa pembelajaran dengan berbantuan macromedia flashpada materi kelarutan dan hasil kali kelarutan juga menunjukkan adanya peningkatkan motivasi dan prestasi belajar siswa (8). Penelitian berikutnya menunjukkan bahwa hasil belajar siswa dalam pembelajaran asam-basa berbantuan macromedia flash lebih tinggi dari siswa yang diajar tidak menggunakan media (9). Hal ini disebabkan oleh adanya penyajian gambar-gambar dan animasi yang dapat membuat rasa ingin tahu siswa menjadi lebih lebih besar, sehingga siswa lebih cepat dan mudah memahami materi kimia tersebut. Penelitian sejenis juga menunjukkan adanya peningkatan aktivitas guru dan siswa ketika pembelajaram pada materi larutan penyangga memanfaatkan macromedia flash. Selain tersebut juga dapat meningkatkanhasil belajar siswa (kognitif, afektif, dan psikomotorik)(10).

Merujuk latar belakang dan kajian pustaka di atas, rumusan masalah dalam penelitian ini adalah: Bagaimana efektifitas penggunaan model pembelajaran langsung berbantuan macromedia flash pada materi sifat koligatif larutan siswa kelas XII MA AlKhoiriyah Dalegan Panceng Gresik.Penelitian ini bertujuan untuk mengetahui efektifitas penggunaan model pembelajaran langsung berbantuan macromedia flash pada materi sifat koligatif larutan siswa kelas XII MA AlKhoiriyah Dalegan Panceng Gresik. 


\section{METODE}

Rancangan penelitian yang digunakan adalah analisis deskriptif, yaitu rancangan penelitian yang mencoba untuk mendeskripsikan suatu kejadian atau gejala peristiwa secara sistematis dan akurat serta mendalam. Siswa kelas XII Semester Ganjil Tahun Ajaran 2018/2019MA Al-Khoiriyah Dalegan Panceng Gresik merupakan subjek dalam penelitian ini. Objek penelitian adalah mata pelajaran kimia materi sifat koligatif larutan. Tahapan penelitian ini terdiri 2 (dua) tahap, yaitu pra penelitian dan mengatasi kesulitan belajar sifat koligatif larutan dengan menerapkan model pembelajaran langsung berbantuan macromedia flash. Urutan-urutan penelitian tersebut dijabarkan berikut ini.

1. Pra Penelitian

Pra penelitian dilaksanakan dengan tujuan mengetahui gambaran awal tentang materi kimia yang menjadi momok (dirasa sulit) bagi kebanyakan siswa. Pra penelitian ini dilakukan dengan teknik wawancara dengan beberapa guru dan siswa di 3 (tiga) kecamatan yang ada di Kabupaten Gresik (Panceng, Ujung Pangkah, dan Dukun).

2. Mengatasi Kesulitan Belajar Sifat Koligatif Larutan dengan Menerapkan Model Pembelajaran Langsung Berbantuan Macromedia Flash

Untuk mengetahui efektifitas penerapan model pembelajaran langsung berbantuan macromedia flash diukur dengan 2 (dua) indikator, yaitu:

a. Aktifitas siswa selama proses pembelajaran menggunakan model pembelajaran langsung berbantuan macromedia flash. Instrumen yang digunakan adalah lembar pengamatan aktifitas siswa selama kegiatan belajar mengajar.

b. Tingkat ketuntasan belajar siswa setelah pembelajaran menerapkan model pembelajaran langsung berbantuan macromedia flash. Instrumen yang digunakan adalah tes tulis yang diberikan setelah kegiatan pembelajaran berakhir.

Variabel penelitian yangdianalisis adalah aktifitas siswa selama kegiatan belajar mengajar menggunakan media pembelajaran berbasis macromedia flash dan tingkat ketuntasan belajar siswa setelah kegiatan belajar mengajar (KBM). Teknik pengumpulan data terdiri atas:

1. Pengamatan Kelas

Pengamatan kelas digunakan untuk mengumpulkan data penelitian mengenai aktifitas siswa (ranah afektif) selama proses kegiatan pembelajan menggunakan model pembelajaran langsung berbantuan macromedia flash. Macromedia flash yang digunakan adalah multimedia Sifat Koligatif Larutan yang dikembangkan oleh (11). Pengamat atau observer sejumlah 2 (dua) orang yang bertugas untuk menilai langkah-langkah pembelajaran dengan menggunakan instrumen pengamatan dan rubrik. Pengamat atau observer merupakan guru Kimia dari MA Al-Khoiriyah Dalegan Panceng Gresik.

2. Pemberian Tes (Tes Hasil Belajar)

Tes ini digunakan untuk mengetahui tingkat ketuntasan belajar siswa. Tes diberikan setelah KBM menggunakan model pembelajaran langsung berbantuan macromedia flash.

Teknik analisis data penelitian ini adalah sebagai berikut:

1. Analisis Data Hasil Pengamatan Aktifitas Siswa

Data yang diperoleh melalui rubrik penilaian afektif dianalisis secara deskriptif untuk mengetahui tingkat keaktifan siswa selama pembelajaran.

2. Analisis Data Hasil Tes

Data yang diperoleh dari tes hasil belajar dimasukkan dalam format analisis hasil belajar, kemudian masing-masing siswa diskor dengan ketentuan sebagai berikut.

$\%$ ketercapaian $=\frac{\text { Jumlahyangdicapaisiswa }}{\text { Jumlahskorseluruhsoal }} \times 100 \%$ 
Siswa dikatakan tuntas belajarnya jika mencapai nilai lebih besar atau sama dengan KKM.

\section{HASILDAN PEMBAHASAN}

Pembelajaran sifat koligatif larutan berbantuan macromedia flash dalam penelitian ini menggunakan multimedia yang telah dikembangkan oleh Artanti (2009)(11) dan telah memiliki validitas sebesar 79,6\%. Tampilan depan (cover) multimedia Sifat Koligatif Larutan disajikan dalam Gambar 1.

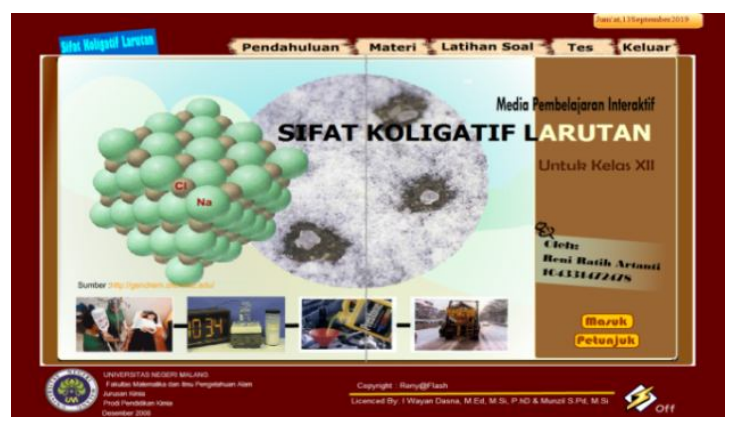

Gambar 1. Tampilan Depan (Cover) Multimedia Sifat Koligatif Larutan

Efektifitas model pembelajaran langsung berbantuan macromedia flash dalam penelitian ini diukur berdasarkan 2 (dua) indikator sebagai berikut.

\section{Hasil Tes}

Tes dilakukan 2 (dua) kali, yaitu tes awal yang bertujuan untuk mengetahui kemampuan awal siswa dan tes akhir yang dilakukan setelah seluruh pembelajaran sifat koligatif larutan selesai. Tujuan dari dilaksanakan tes akhir adalah untuk mengetahui kemampuan kognitif siswa, sekaligus untuk mengetahui ketuntasan belajar siswa setelah dibelajarkan menggunakan model pembelajaran langsung berbantuan macromedia flash.

Nilai rata-rata kognitif siswa tersaji dalam Tabel 1 sebagai berikut.

Tabel 1. Hasil Tes Kognitif Siswa

\begin{tabular}{ccccc}
\hline Perlakuan & N & $\begin{array}{c}\text { Nilai } \\
\text { Terendah }\end{array}$ & $\begin{array}{c}\text { Nilai } \\
\text { Tertinggi }\end{array}$ & $\begin{array}{c}\text { Rata- } \\
\text { rata }\end{array}$ \\
\hline Tes Awal & 17 & 55 & 85 & 66 \\
\hline Tes Akhir & 17 & 76 & 82 & 78 \\
\hline
\end{tabular}

Berdasarkan data Tabel 1, dapat diketahui bahwa nilai rata-rata kognitif pada materi sifat koligatif larutan mengalami peningkatan setelah siswa dibelajarkan menggunakan model pembelajaran langsung berbasis macromedia flash. Tabel 1 menunjukkan bahwa nilai nilai rata-rata dan nilai terendah pada tes akhir berturut-turut adalah 78 dan 76, sedangkan nilai KKM adalah 75. Karenanilai terendah pada tes akhir lebih tinggi dari KKM, maka dapat disimpulkan bahwa semua siswa Kelas XII MA Al-Khoiriyah Dalegan Panceng Gresik mengalami ketuntasan belajar pada materi sifat koligatif larutan setelah dibelajarkan menggunakan model pembelajaran langsung berbantuan macromedia flash.

Adapun analisis ketuntasan setiap butir soal tes sifat koligatif larutan disajikan dalam tabel 2 di bawah ini.

Tabel 2. Analisis Ketuntasan Butir Soal Koligatif Larutan

\begin{tabular}{|c|c|c|c|c|c|c|}
\hline \multirow{2}{*}{$\begin{array}{l}\text { No. } \\
\text { Soal }\end{array}$} & \multirow{2}{*}{ Materi } & \multicolumn{4}{|c|}{ Prosentase Siswa yang Menjawab Benar } & \multirow{2}{*}{$\begin{array}{c}\text { Ketuntasan } \\
\text { Butir Soal }\end{array}$} \\
\hline & & Tes Awal & $\%$ & Tes Akhir & $\%$ & \\
\hline 1. & \multirow[t]{6}{*}{ Penurunan titik beku larutan } & 1 & 5,9 & 12 & 70,6 & Tuntas \\
\hline 2. & & 6 & 35,3 & 14 & 82,4 & Tuntas \\
\hline 4. & & 3 & 17,6 & 14 & 82,4 & Tuntas \\
\hline 5. & & 12 & 70,6 & 13 & 76,5 & Tuntas \\
\hline 6. & & 12 & 70,6 & 15 & 88,2 & Tuntas \\
\hline 7. & & 10 & 58,8 & 15 & 88,2 & Tuntas \\
\hline
\end{tabular}

Vol. 3, No. 2, December 2019 (65-71) 


\begin{tabular}{|c|c|c|c|c|c|c|}
\hline 14. & & 15 & 88,2 & 15 & 88,2 & Tuntas \\
\hline 15. & & 5 & 29,4 & 8 & 47,0 & Tidak Tuntas \\
\hline 24. & & 7 & 41,2 & 14 & 82,4 & Tuntas \\
\hline 27. & & 10 & 58,8 & 9 & 52,9 & Tuntas \\
\hline 29. & & 9 & 52,9 & 15 & 88,2 & Tuntas \\
\hline 3. & \multirow[t]{5}{*}{ Kenaikan titik didih larutan } & 8 & 47,0 & 14 & 82,4 & Tuntas \\
\hline 13. & & 15 & 88,2 & 15 & 88,2 & Tuntas \\
\hline 16. & & 3 & 17,6 & 8 & 47,0 & Tidak Tuntas \\
\hline 21. & & 4 & 23,5 & 15 & 88,2 & Tuntas \\
\hline 26. & & 7 & 41,2 & 14 & 82,4 & Tuntas \\
\hline 8. & \multirow[t]{5}{*}{ Stoikiometri larutan } & 11 & 64,7 & 12 & 70,6 & Tuntas \\
\hline 9. & & 15 & 88,2 & 15 & 88,2 & Tuntas \\
\hline 10. & & 7 & 41,2 & 14 & 82,4 & Tuntas \\
\hline 20. & & 3 & 17,6 & 13 & 76,5 & Tuntas \\
\hline 22. & & 6 & 35,3 & 15 & 88,2 & Tuntas \\
\hline 11. & Fraksi mol & 8 & 47,0 & 14 & 82,4 & Tuntas \\
\hline 12. & \multirow[t]{2}{*}{ Penurunan tekanan uap } & 3 & 17,6 & 14 & 82,4 & Tuntas \\
\hline 25. & & 5 & 29,4 & 7 & 41,2 & Tidak Tuntas \\
\hline 17. & \multirow[t]{6}{*}{ Tekanan osmotik } & 10 & 58,8 & 14 & 82,4 & Tuntas \\
\hline 18. & & 5 & 29,4 & 15 & 88,2 & Tuntas \\
\hline 19. & & 8 & 47,0 & 10 & 58,8 & Tuntas \\
\hline 23. & & 6 & 35,3 & 14 & 82,4 & Tuntas \\
\hline 28. & & 13 & 76,5 & 15 & 88,2 & Tuntas \\
\hline 30. & & 11 & 64,7 & 13 & 76,5 & Tuntas \\
\hline
\end{tabular}

Berdasarkan data pada Tabel 2 diketahui bahwa pada awal pembelajaran,ketuntasan butir soal tes sebesar $60 \%$ dan $40 \%$ soal lainnya tidak tuntas. Namun, pada akhir pembelajaran diketahui bahwa90\% soal dapat diselesaikan dengan baik oleh siswa (kriteria tuntas), sedangkan $10 \%$ soal tidak tuntas. Dengan demikian dapat disimpulkan bahwa secara keseluruhan, siswa telah memenuhi kriteria ketuntasan belajar pada materi sifat koligatif larutan setelah dibelajarkan menggunakan model pembelajaran langsung berbantuan macromedia flash.

Hasil tersebut selaras dengan penelitian sebelumnya yang dilakukan oleh Mawarni, dkk. (2015:36)(8) yang menunjukkan bahwa pembelajaran dengan berbantuan macromedia flash dapat meningkatkan prestasi belajar kimia siswa (materi kelarutan dan hasil kali kelarutan). Selain itu, penelitian sejenis juga telah dilakukan oleh Yusuf, dkk. (2016:342)(9) dimana hasilnya menunjukkan bahwa hasil belajar siswa dalam pembelajaran kimia berbantuan macromedia flash lebih tinggi dari hasil belajar siswa yang diajar tanpa menggunakan media (materi asam-basa).
Dengan demikian, dapat disimpulkan bahwa pembelajaran kimia menggunakan model pembelajaran langsung berbasis macromedia flash dapat meningkatkan prestasi belajar (kognitif) siswa pada materi sifat koligatif larutan.

\section{Hasil Pengamatan Aktivitas Siswa}

Pengamatan aktivitas siswa dilaksanakan selama pembelajaran sifat koligatif larutan. Penilaian pengamatan aktivitas siswa bertujuan untuk menilai bagaimana sikap yang ditunjukkan oleh siswa selama pembelajaran. Lembar pengamatan aktivitas siswa menggunakan skala Likert, dimana skor $5=$ aktivitas sangat tepat, $4=$ aktivitas tepat, $3=$ aktivitas agak tepat, 2 = aktivitas tidak tepat, dan 1 = aktivitas sangat tidak tepat. Hasil penilaian pengamatan aktivitas siswa secara keseluruhan disajikan dalam Tabel 3.

Berdasarkan data pada Tabel 3, diketahui bahwa aktivitas siswa selama pembelajaran berada pada skor 4 dan 5. Artinya, aktivitas pembelajaran yang dilakukan oleh siswa adalah aktivitas yang tepat sesuai dengan sintaks model pembelajaran langsung. 
Tabel 3. Hasil Penilaian Pengamatan Aktivitas Siswa

\begin{tabular}{|c|c|c|c|c|c|c|c|c|c|c|c|}
\hline \multirow{3}{*}{ No. } & \multirow{3}{*}{ Aspek Aktititas } & \multicolumn{10}{|c|}{ Jumlah Siswa yang Memperoleh Skor } \\
\hline & & \multicolumn{2}{|c|}{1} & \multicolumn{2}{|c|}{2} & \multicolumn{2}{|c|}{3} & \multicolumn{2}{|c|}{4} & \multicolumn{2}{|c|}{5} \\
\hline & & Jml & $\%$ & Jml & $\%$ & Jml & $\%$ & Jml & $\%$ & Jml & $\%$ \\
\hline 1. & $\begin{array}{l}\text { Menjawab salam dan berdoa } \\
\text { bersama }\end{array}$ & 0 & 0 & 0 & 0 & 0 & 0 & 5 & 29 & 12 & 71 \\
\hline 2. & $\begin{array}{l}\text { Mendengarkan/memperhatikan } \\
\text { penjelasan guru }\end{array}$ & 0 & 0 & 0 & 0 & 0 & 0 & 12 & 71 & 5 & 29 \\
\hline 3. & Mengerjakan latihan soal & 0 & 0 & 0 & 0 & 0 & 0 & 9 & 53 & 8 & 47 \\
\hline 4. & $\begin{array}{l}\text { Tanya jawab antar guru dan } \\
\text { siswa }\end{array}$ & 0 & 0 & 0 & 0 & 0 & 0 & 9 & 53 & 8 & 47 \\
\hline 5. & $\begin{array}{l}\text { Menyelesaikan tugas yang } \\
\text { diberikan oleh guru }\end{array}$ & 0 & 0 & 0 & 0 & 0 & 0 & 11 & 65 & 6 & 35 \\
\hline & Jumlah Total & 0 & & 0 & & 0 & & 46 & & 39 & \\
\hline
\end{tabular}

Hasil pengamatan aktivitas siswa pada aspek 1 (menjawab salam dan berdoa bersama) berada di skor 5,artinya siswa merespon dengan baik aktivitas guru pada fase satu (mempersiapkan siswa dan menyampaikan tujuan). Untuk aspek 2 (mendengarkan/memperhatikan penjelasan guru) skor yang diperoleh 4, artinya aktivitas siswa sesuai dengan fase dua, yaitu guru menyampaikan materi. Aspek 3 dari aktivitas siswa (mengerjakan latihan soal), skor tertinggi yang diperoleh yaitu 4,dimana aktivitas pembimbingan latihan soal oleh guru berjalan dengan baik (fase 3 ). Tanya jawab antar guru dengan siswa (aspek 4) diperoleh skor 4, dimana skor tersebut menunjukkan bahwa fase 4 (guru mengecek pemahan siswa) benar-benar telah terlaksana. Aspek aktivitas siswa yang terakhir, yaitu menyelesaikan tugas yang diberikan oleh guru (fase 5) diperoleh skor tertinggi 4 , artinya siswa melaksanakan perintah guru sesuai dengan sintaks model pembelajaran langsung, yaitu guru memberi kesempatan latihan soal lanjutan. Dengan demikian, dari hasil penelitian dapat disimpulkan bahwa sintaks (fase) model pembelajaran langsung berbantuan macromedia flash sudah terlaksana dengan baik.

Hasil tersebut sesuai dengan penelitian yang dilakukan oleh Akbas \& Pektas (2011)(6) dimana hasilnya menunjukkan bahwa penggunaan "papan tulis interaktif" berbasis macromedia flash mampu memotivasi siswa untuk aktif dalam pembelajaran, menciptakan suasana belajar yang menarik, antusias, dan menyenangkan.Dengan demikian, dapat disimpulkan bahwa model pembelajaran langsung berbantuan macromedia flash dapat meningkatkan aktivitas belajar siswa dalam materi sifat koligatif larutan. Hasil tersebut juga selaras dengan penelitian sebelumnya yang dilakukan oleh Mawarni, dkk. (2015:36)(8) yang menunjukkan bahwa pembelajaran dengan berbantuan macromedia flash dapat meningkatkan prestasi belajar kimia siswa (materi kelarutan dan hasil kali kelarutan). Selain itu, penelitian sejenis juga telah dilakukan oleh Yusuf, dkk. (2016:342)(9) dimana hasilnya menunjukkan bahwa hasil belajar siswa dalam pembelajaran kimia berbantuan macromedia flash lebih tinggi dari hasil belajar siswa yang diajar tanpa menggunakan media (materi asam-basa). Dengan demikian, dapat disimpulkan bahwa pembelajaran kimia menggunakan model pembelajaran langsung berbasis macromedia flash dapat meningkatkan prestasi belajar (kognitif) siswa pada materi sifat koligatif larutan. 


\section{SIMPULAN DAN SARAN}

Berdasarkan hasil dan pembahasan, maka simpulan yang dapat diambil dari penelitian ini, yaitu: Penerapan model pembelajaran langsung berbantuan macromedia flash efektif untuk menangani kesulitan siswa MA AlKhoiriyah Dalegan Panceng Gresik pada materi sifat koligatif larutan. Saran untuk

\section{DAFTAR PUSTAKA}

[1] Istiani, W., Asrial, \& Hsb, M. H. Effendi. 2014. Pengaruh Penggunaan Media Laboratorium Virtual terhadap Hasil Belajar Siswa pada Materi Sifat Koligatif Larutan di SMA Negeri 11 Tebo. [Online] [Dikutip: 2018 Maret 21.] http://repository.fkip.unja.ac.id/search/det il/Pengaruh\%20Penggunaan $\% 20$ Media $\%$ 20Laboratorium\%20Virtual\%20Terhadap $\% 20 \mathrm{Hasil} \% 20 \mathrm{Belajar} \% 20$ Siswa\%20Pada $\% 20$ Materi\%20Sifat\%20Koligatif\%20Lar utan\%20Di\%20SMA\%20Negeri\%2011T ebo.html.

[2] Ariyaldi, Putri, A. T., Khalisah, A. N., \& Nurhikma. 2017. Pengaruh Penggunaan Strategi Dynamic Problem Solving Berbasis Conceptual Scaffolding Untuk Meningkatkan Hasil Belajar dan Aktivitas Belajar Peserta Didik Pada Materi Sifat Koligatif Larutan. [Online] [Cited: Agustus 2018, 18.] https://ojs.unm.ac.id/nalar/article/view/48 75.

[3] Suyono dan Hariyanto. 2016. Belajar dan Pembelajaran. 6th. Surabaya: PT. Remaja Rosdakarya.

[4] Kardi, S. \& Nur, M. 2003. Pengantar pada Pengajaran dan Pengelolaan Kelas. Surabaya : University Press.

[5] Tuysuz, Cengiz. 2010. The Effects of the Virtual Laboratory on Students' Achievement and Attitude in Chemistry. [Online]. [Cited: Agustus 2018, 15.] http://mts.iojes.net//userfiles/Article/IOJE S_167.pdf.

[6] Akbas, O., \& Pektas, H. M. 2011. The effects of Using Interactive Whiteboard on The Academic Achievement of University Students. [Online]. [Cited: Agustus 2018, 18.] https://www.eduhk.hk/apfslt/v12_issue2/a kbar/index.htm. penelitian terhadap pembelajaran sifat koligatif larutan perlu diperdalam lagi, karena dalam pembelajaran masih banyak ditemukan praktik menghafal rumus dan terpaku pada latihan soal semata. Hal tersebut menjadikan siswa kurang memahami konsep sifat koligatif larutan dan lebih terpaku dalam menyelesaikan soal-soal perhitungan matematis.

[7] Tatli, Z., \& Ayas, A. 2013. Effect of a Virtual Chemistry Laboratory on Students' Achievement. [Online]. [Cited: Agustus 2018, 18.] https://drive.google.com/file/d/12IEJSDQ LIXUqvDFM1k7GcQJg-2AHFiHm/view.

[8] Mawarni E., Mulyani, B., \& Yamtinah, S. 2015. Penerapan Peer Tutoring Dilengkapi Animasi Macromedia Flash dan Handout Untuk Meningkatkan Motivasi Berprestasi dan Prestasi Belajar Siswa Kelas XI IPA 4 SMAN 6 Surakarta Tahun Pelajaran 2013/2014 pada Materi Kelarutan dan Hasil Kali Kelarutan. [Online] [Cited: Agustus 2018, 14.] https://jurnal.fkip.uns.ac.id/index.php/kim ia/article/view/4883.

[9] Yusuf, N., Sitorus, N., Hsb, Dina A., S., Tiara D., \& Silaban R. 2016. Efektivitas Penggunaan Media Pembelajaran Asam Basa Terhadap Hasil Belajar Siswa Melalui Pendekatan Scientific. [Online] [Cited: Mei 2018, 28.] http://digilib.unimed.ac.id/23759/1/Fullte xt.pdf.

[10] Setiadi, Iswan. 2018. Meningkatkan Hasil Belajar Siswa Melalui Penerapan Model Penemuan Terbimbing pada Materi Larutan Penyangga Berbantuan Macromedia Flash Kelas XI IPA SMA Muhammadiyah 1 Banjarmasin Tahun Pelajaran 2014/2015. [Online]. [Cited: Agustus 2018, 14.] https://ppjp.ulm.ac.id/journal/index.php/q uantum/article/view/4860.

[11] Artanti, R. 2009. Pengembangan Media Pembelajaran Berbantuan Komputer pada Materi Sifat Koligatif Larutan di SMA. Malang: Universitas Negeri Malang. Skripsi tidak diterbitkan. 